\title{
Silicone Oil in the Aphakic Eye: The Influence of a Six o'clock Peripheral Iridectomy
}

\author{
H. C. LAGANOWSKI and P. K. LEAVER \\ London
}

\begin{abstract}
Summary
Complications after six months, in a series of 44 aphakic eyes treated by vitrectomy and fluid/silicone-oil exchange with six o'clock (Ando) peripheral iridectomy, are reported. Comparisons are made with the complications after six months in a similar series treated prior to the introduction of the six o'clock iridectomy. It is concluded that a patent six o'clock iridectomy is effective in reducing the complications of intraocular silicone oil in the aphakic eye.
\end{abstract}

The use of intraocular silicone oil in the treatment of complicated retinal detachments is well established. ${ }^{1-28}$ In the aphakic eye, however, it is associated with a high risk of glaucoma and keratopathy. ${ }^{2,6.21 .29-35}$ In an attempt to limit these complications it was our practice to perform a superior sector iridectomy (SI) (Fig. 1a). In a communication to the American Journal of Ophthalmology in 1985, Ando $^{37}$ suggested that it is more logical to create a peripheral iridectomy (PI) at the six o'clock position. Since then we have performed this procedure in all aphakic eyes treated with silicone-oil injection (Fig. 1b).

This paper reports the results of a retrospective study of 88 aphakic eyes treated with silicone oil, 44 cases having been treated after (group I) and 44 prior to (group II), the introduction of the six o'clock PI.

The incidence of anterior segment complications in the two groups is compared in an attempt to evaluate the effect of the six o'clock PI.

\section{Patients and Methods}

The records of 88 consecutive patients treated with intraocular silicone oil at the High Holborn branch of Moorfields Eye Hospital between March 1982 and March 1987 were reviewed. Thirty-six patients were female and 52 male, their ages ranging from 12 to 78 years with a mean of 52 years.

\section{Group I}

In the group with six o'clock PIs silicone oil was used to treat proliferative vitreoretinopathy (PVR) in 34 cases, giant retinal tears (GRTs) in seven and other retinal pathology in three (Table I)

Twenty-one eyes were aphakic prior to silicone-oil injection, 15 underwent lens extraction at the time that silicone oil was used and eight had lens extraction performed subsequently. The lens was removed by intracapsular extraction in 21 eyes, by pars plana lensectomy in 13 and by extracapsular extraction combined with capsulectomy in ten (Table I).

In eyes which were already aphakic prior to or which were rendered aphakic at the beginning of the silicone-oil injection procedure a six o'clock PI was performed, after completion of the vitrectomy, using the Ocutome via the pars plana. In those eyes rendered aphakic some time after the use of silicone oil a six o'clock PI was performed, after the lens had 


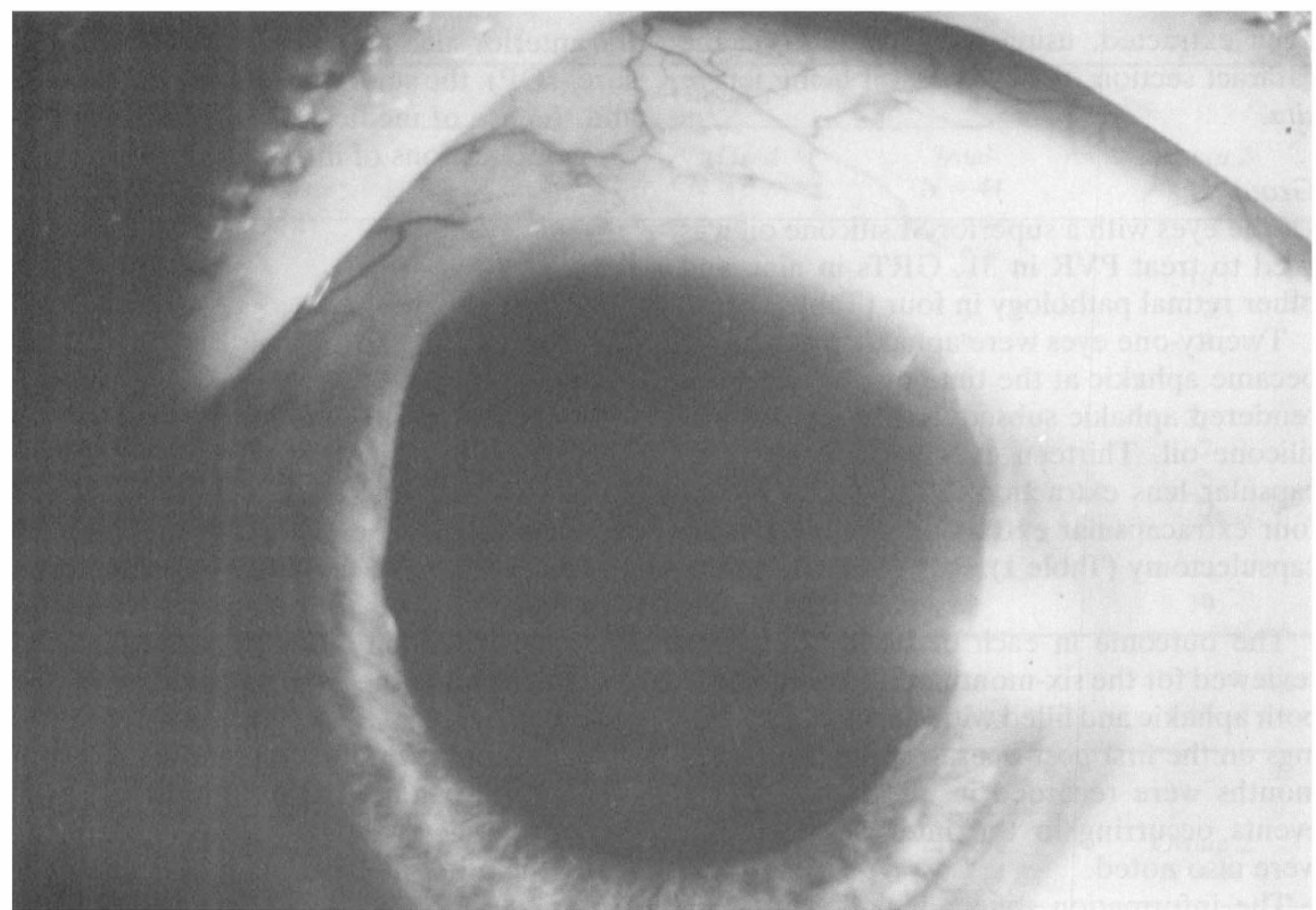

Fig. 1a Superior sector iridectomy in an aphakic eye filled with silicone oil to treat retinal detachment complicated by proliferative vitreoretinopathy.

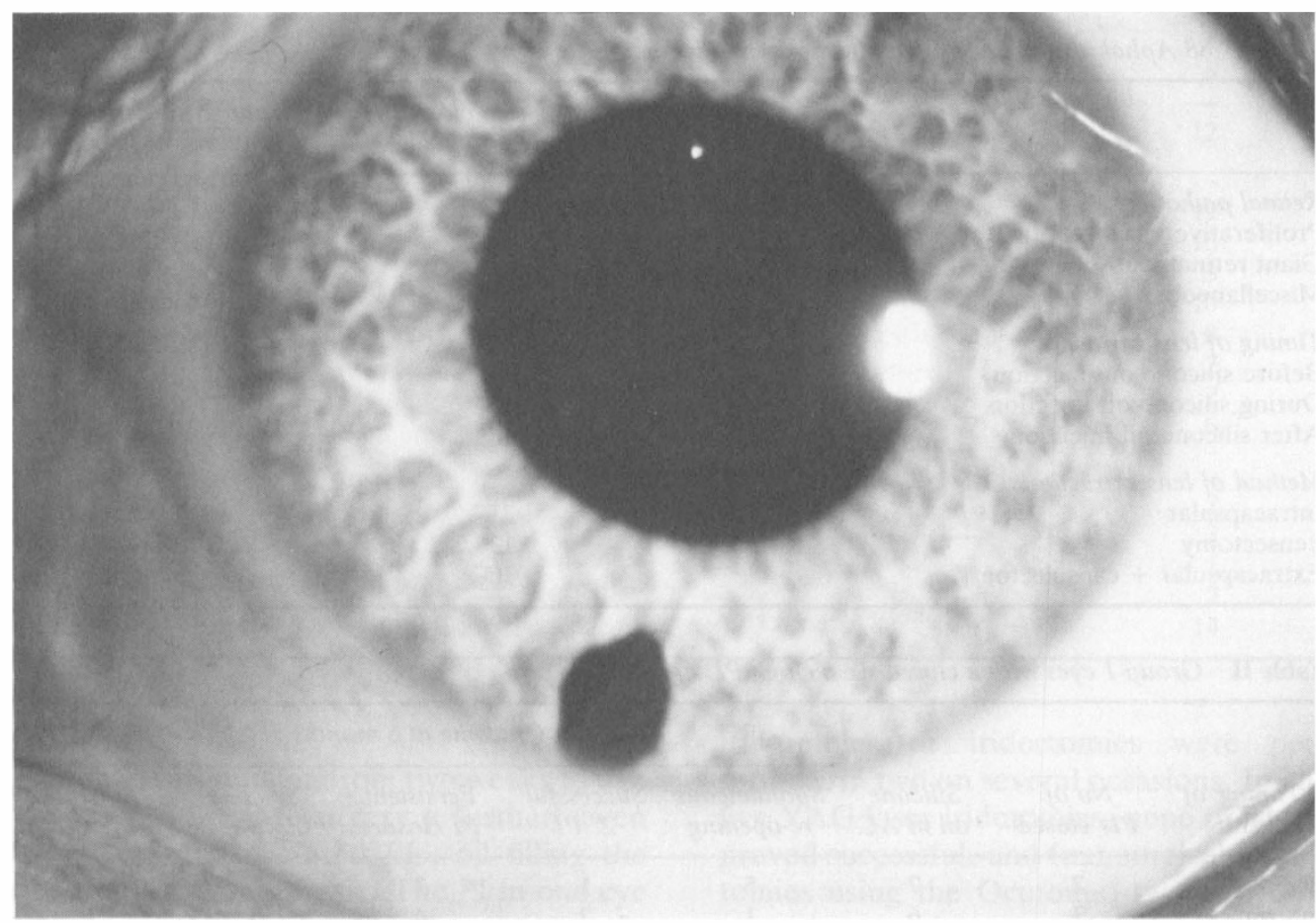

Fig. 1b A similar case treated after the introduction of the six o'clock iridectomy. 
been extracted, using the Ocutome via the cataract section, the silicone oil being left in situ.

\section{Group II}

Of the eyes with a superior SI silicone oil was used to treat PVR in 31, GRTs in nine and other retinal pathology in four (Table I).

Twenty-one eyes were aphakic prior to, 21 became aphakic at the time of and two were rendered aphakic subsequent to injection of silicone oil. Thirteen eyes underwent intracapsular lens extraction, 27 lensectomy and four extracapsular extraction combined with capsulectomy (Table I).

The outcome in each of the 88 eyes was reviewed for the six-month period after it was both aphakic and filled with silicone oil. Findings on the first post-operative day and at six months were recorded in all cases and any events occurring in the intervening period were also noted.

The information sought included patency of the six o'clock PI (in Group I), position of the anterior silicone-oil face, intraocular pressure (IOP), the status of the cornea and retina and the use of medical or surgical treatment for complications of intraocular silicone oil.

\section{Results}

\section{Group I}

1. Patency of the six o'clock PI (Table II) Day One

On the first post-operative day seven out of 44 six o'clock PIs were effectively closedone by blood, four by silicone oil and two by residual iris tissue. The anterior chambers of all seven eyes were filled with silicone oil. In five eyes the PI became patent spontaneously and oil returned to the posterior segment after the first post-operative day; all five PIs were still patent at six months. Of the two eyes with incomplete PIs, one still had a non-patent PI at six months, although oil no longer filled the anterior chamber, and the other had a second inferior PI performed after six weeks which remained patent at six months.

Table I 88 Aphakic eyes treated with intraocular silicone oil

\begin{tabular}{lcc}
\hline & $\begin{array}{c}\text { Group 1 (6 o'clock PI) } \\
\text { N=44 }\end{array}$ & $\begin{array}{c}\text { Group } 2 \text { (Superior SI) } \\
N=44\end{array}$ \\
\hline $\begin{array}{l}\text { Retinal pathology } \\
\text { Proliferative vitreoretinopathy }\end{array}$ & 34 & 31 \\
Giant retinal tear & 7 & 9 \\
Miscellaneous & 3 & 4 \\
Timing of lens extraction & & 21 \\
Before silicone oil injection & 21 & 21 \\
During silicone oil injection & 15 & 2 \\
After silicone oil injection & 8 & 13 \\
Method of lens extraction & & 27 \\
Intracapsular & 21 & 4 \\
Lensectomy & 13 & 10 \\
Extracapsular + capsulectomy & 13 & \\
\hline
\end{tabular}

Table II Group 1 eyes with a closed six o'clock PI

Outcome at 6 months

\begin{tabular}{lccccccc}
\cline { 3 - 7 } $\begin{array}{c}\text { Timing of } \\
\text { closure }\end{array}$ & $\begin{array}{c}\text { No of } \\
\text { PIs closed }\end{array}$ & $\begin{array}{c}\text { Silicone } \\
\text { oil in AC }\end{array}$ & $\begin{array}{c}\text { Spontaneous } \\
\text { re-opening }\end{array}$ & $\begin{array}{c}\text { Successful } \\
2^{\circ} \text { PI }\end{array}$ & $\begin{array}{c}\text { Persistent } \\
\text { PI closure }\end{array}$ & $\begin{array}{c}\text { Silicone } \\
\text { oil in AC }\end{array}$ & $\begin{array}{c}\text { Silicone } \\
\text { oil removed }\end{array}$ \\
\hline Day 1 & 7 & 7 & 5 & 1 & 1 & -1 & 1 \\
Interim & 7 & 6 & 1 & 2 & 4 & 3 & 1 \\
6 months & 5 & 3 & - & - & 5 & 3 & - \\
\hline
\end{tabular}


Table III Intraocular pressures on day one

\begin{tabular}{|c|c|c|c|c|}
\hline & \multicolumn{3}{|c|}{ Group 1} & \multirow[b]{2}{*}{$\begin{array}{c}\text { Group } 2 \\
N=44\end{array}$} \\
\hline & $\begin{array}{c}\text { PI open } \\
N=37\end{array}$ & $\begin{array}{c}\text { PI closed } \\
N=7\end{array}$ & $\begin{array}{c}\text { Total } \\
N=44\end{array}$ & \\
\hline \multicolumn{5}{|l|}{ Eyes with normal IOP } \\
\hline $\mathrm{IOP}<25 \mathrm{~mm} \mathrm{Hg}$ & 21 & 1 & 22 & 19 \\
\hline Silicone oil in $\mathrm{AC}$ & - & 1 & 1 & 2 \\
\hline Retinal detachment & 4 & - & 4 & 4 \\
\hline \multicolumn{5}{|l|}{ Eyes with raised IOP } \\
\hline $\mathrm{IOP}>25 \mathrm{~mm} \mathrm{Hg}$ & 16 & 6 & 22 & 25 \\
\hline IOP $>40 \mathrm{~mm} \mathrm{Hg}$ & - & 5 & 5 & 7 \\
\hline Silicone oil in $\mathrm{AC}$ & - & 6 & 6 & 5 \\
\hline Retinal detachment & 2 & 2 & 4 & 7 \\
\hline \multicolumn{5}{|l|}{ Treatment instigated } \\
\hline :AC paracentesis & - & 4 & 4 & - \\
\hline :Medical & 8 & 5 & 13 & 10 \\
\hline
\end{tabular}

Table IV Intraocular pressures in interim

\begin{tabular}{|c|c|c|c|c|}
\hline & \multicolumn{3}{|c|}{ Group 1} & \multirow[b]{2}{*}{$\begin{array}{c}\text { Group } 2 \\
N=44\end{array}$} \\
\hline & $\begin{array}{c}\text { Open PI } \\
N=35\end{array}$ & $\begin{array}{c}\text { Closed PI } \\
N=9\end{array}$ & $\begin{array}{c}\text { Total } \\
N=44\end{array}$ & \\
\hline \multicolumn{5}{|l|}{ Eyes with normal IOP } \\
\hline $\mathrm{IOP}<25 \mathrm{~mm} \mathrm{Hg}$ & 25 & 5 & 30 & 25 \\
\hline :without Rx & 22 & 4 & 26 & 24 \\
\hline :with Rx & 3 & 1 & 4 & 1 \\
\hline Silicone oil in AC & - & 3 & 3 & 6 \\
\hline Silicone oil removed & 1 & 1 & 2 & - \\
\hline Retinal detachment & 4 & - & 4 & 12 \\
\hline \multicolumn{5}{|l|}{ Eyes with raised IOP } \\
\hline $\mathrm{IOP}>25 \mathrm{~mm} \mathrm{Hg}$ & 10 & 4 & 14 & 19 \\
\hline :without Rx & 6 & 1 & 7 & 16 \\
\hline :with Rx & 4 & 3 & 7 & 3 \\
\hline $\mathrm{IOP}>40 \mathrm{~mm} \mathrm{Hg}$ & 3 & 3 & 6 & 10 \\
\hline :without Rx & 1 & 1 & 2 & 8 \\
\hline :with Rx & 2 & 2 & 4 & 2 \\
\hline Silicone oil in AC & - & 4 & 4 & 7 \\
\hline Retinal detachment & 5 & 2 & 7 & 6 \\
\hline \multicolumn{5}{|l|}{ Treatment instigated } \\
\hline :Paracentesis & - & 1 & 1 & 2 \\
\hline :Silicone oil removal & 1 & - & - & 3 \\
\hline :Trabeculectomy & - & - & - & 1 \\
\hline :Molteno tube & - & - & - & 2 \\
\hline :Medical & 5 & 1 & 6 & 14 \\
\hline
\end{tabular}

\section{Interim}

At intervals ranging from two weeks to five months following surgery a further seven eyes developed closed PIs, oil filling the anterior chamber in six. The PI in one eye reopened spontaneously after one month. In four eyes additional inferior peripheral iridotomies or iridectomies were performed, in two on several occasions. In all, five YAG laser iridotomies, none of which proved successful, and four surgical iridectomies using the Ocutome, two of which proved successful, were performed.

Thus, at six months three out of seven 
eyes had a patent PI and an oil-free anterior chamber, while in four the PI remained closed, oil filling the anterior chamber in three and having been removed from one.

\section{Six months}

At six months a further five eyes were noted to have a closed PI, oil filling the anterior chamber in three.

\section{Intraocular Pressure}

Day One (Table III)

On the first post-operative day 22 of the 44 eyes with a six o'clock PI had an IOP of less than $25 \mathrm{mmHg}$. One of these eyes, in which the retina had been successfully attached, had a closed PI and an oil-filled anterior chamber.

Twenty-two eyes in Group I had an IOP of greater than $25 \mathrm{mmHg}$ on the first postoperative day. In six the PI was closed and oil filled the anterior chamber. Five of these eyes had an IOP of greater than $40 \mathrm{mmHg}$ and in four a paracentesis was necessary to relieve acute oil-induced pupillary block. Thirteen of the 22 eyes with raised IOP required medical treatment.

\section{Interim (Table IV)}

During the six months following surgery 30 eyes in Group I maintained an IOP of less than $25 \mathrm{mmHg}$, with the aid of timolol in four. Five of these eyes had a closed PI, oil filling the anterior chamber in three: of these three, one was on timolol, one underwent removal of silicone oil at three months and the third had a successful PI performed, with a return of oil to the posterior segment, five months following surgery. In all five of the eyes with a closed PI and normal IOP the retina was attached.

Fourteen eyes in Group I (12 of which had raised IOP on day one) had IOPs of greater than $25 \mathrm{mmHg}$ (greater than 40 $\mathrm{mmHg}$ in six) during the six month follow-up period. Seven of these eyes were already being treated with timolol and it was commenced in a further six. Four eyes with raised IOP (greater than $40 \mathrm{mmHg}$ in three) had a closed PI and an oil-filled anterior chamber. The one eye in which the
PI had been closed since day one required a second anterior chamber paracentesis to relieve acute pupillary block. All four eyes with raised IOP and a closed PI had a secondary PI performed, but this was successful in only two cases. Of the ten eyes with raised IOP and a patent PI, two had glaucoma prior to surgery, and in one raised IOP developed following additional silicone-oil injection. No reason for raised IOP was identified in the other seven eyes.

\section{Six Months (Table V)}

At six months 37 eyes in Group I had an IOP of less than $25 \mathrm{mmHg}$, with the aid of timolol in nine. Seven had closed PIs, oil filling the anterior chamber in five and having been removed from one. Normal IOP in the eyes with oil-filled anterior chambers was achieved by medication in one and in another three was probably associated with persistent retinal detachment.

Seven eyes in Group I had an IOP of greater than $25 \mathrm{mmHg}$, despite medication in six, at six months. In three the PI was closed: oil filled the anterior chamber in one and another exhibited rubeosis iridis. One of the four eyes with a patent PI had glaucoma prior to surgery. There was no obvious reason for raised IOP in the other three eyes.

\section{Corneal Status (Table VI)}

At six months keratopathy was evident in six of the 44 eyes with a six o'clock PI. Four of these eyes had a closed PI, oil filling the anterior chamber in three and having been removed from one three months earlier. One case had a closed PI and an oil-filled anterior chamber for a period of three months, following which a new, successful PI was performed. In the remaining eye keratopathy developed in spite of a functioning PI.

Two of the six eyes which developed keratopathy had an IOP of greater than $25 \mathrm{mmHg}$ on the first post-operative day, but for the remainder of the six-month follow-up period the IOP was normal in all six.

Of the six eyes with keratopathy one, in which the PI was closed with oil filling the 
Table V Intraocular pressures at 6 months

\begin{tabular}{|c|c|c|c|c|}
\hline & \multicolumn{3}{|c|}{ Group 1} & \multirow[b]{2}{*}{$\begin{array}{c}\text { Group } 2 \\
N=44\end{array}$} \\
\hline & $\begin{array}{c}\text { Open PI } \\
N=34\end{array}$ & $\begin{array}{c}\text { Closed PI } \\
\quad N=10\end{array}$ & $\begin{array}{c}\text { Total } \\
N=44\end{array}$ & \\
\hline \multicolumn{5}{|l|}{ Eyes with normal IOP } \\
\hline $\mathrm{IOP}<25 \mathrm{~mm} \mathrm{Hg}$ & 30 & 7 & 37 & 32 \\
\hline :without Rx & 22 & 6 & 28 & 23 \\
\hline :with $\mathrm{Rx}$ & 8 & 1 & 9 & 9 \\
\hline Silicone oil in AC & - & 5 & 5 & 7 \\
\hline Silicone oil removed & 1 & 1 & 2 & 3 \\
\hline Retinal detachment & 4 & 3 & 7 & 12 \\
\hline \multicolumn{5}{|l|}{ Eyes with raised IOP } \\
\hline $\mathrm{IOP}>25 \mathrm{~mm} \mathrm{Hg}$ & 4 & 3 & 7 & 12 \\
\hline :without Rx & - & 1 & 1 & 6 \\
\hline :with Rx & 4 & 2 & 6 & 6 \\
\hline $\mathrm{IOP}>40 \mathrm{~mm} \mathrm{Hg}$ & - & 2 & 2 & 4 \\
\hline :without Rx & - & - & - & 2 \\
\hline :with Rx & - & 2 & 2 & 2 \\
\hline Silicone oil in $\mathrm{AC}$ & - & 1 & 1 & 4 \\
\hline Silicone oil removed & 1 & - & 1 & - \\
\hline Retinal detachment & 1 & 1 & 2 & 8 \\
\hline
\end{tabular}

Table VI Eyes with keratopathy at 6 months

\begin{tabular}{|c|c|c|c|c|}
\hline & \multicolumn{3}{|c|}{ Group 1} & \multirow[b]{2}{*}{$\begin{array}{c}\text { Group } 2 \\
N=44\end{array}$} \\
\hline & $\begin{array}{c}\text { Open PI } \\
N=30\end{array}$ & $\begin{array}{c}\text { Closed PI } \\
\text { after day } 1 \\
N=14\end{array}$ & $\begin{array}{c}\text { Total } \\
N=44\end{array}$ & \\
\hline Keratopathy & 1 & 5 & 6 & 17 \\
\hline Silicone oil in AC & - & 5 & 5 & 12 \\
\hline Position of oil face unknown & - & - & - & 5 \\
\hline IOP $>25 \mathrm{~mm} \mathrm{Hg}$ for several months & - & - & - & 6 \\
\hline Persistent retinal detachment & - & 1 & 1 & 11 \\
\hline
\end{tabular}

anterior chamber at six months, had a persistent retinal detachment.

\section{Group II}

1. Intraocular Pressure

Day One (Table III)

On the first post-operative day normal IOP was recorded in 19 of the 44 eyes with a superior SI. Oil was present in the anterior chamber of two, one of which had a persistent retinal detachment.

Twenty-five eyes in Group II had an IOP of greater than $25 \mathrm{mmHg}$ on day one. This was associated with oil in the anterior chamber in five. Seven had an IOP of greater than $40 \mathrm{mmHg}$, but this resolved rapidly with posturing and no emergency surgical measures were necessary. Ten of the eyes with raised IOP required medical therapy.

Interim (Table IV)

During the six months following surgery 25 eyes in Group II had an IOP of less than $25 \mathrm{mmHg}$, with the aid of timolol in one. Six of these eyes had anterior chambers filled with oil: in all six the retina was detached.

Nineteen eyes in Group II had an IOP of greater than $25 \mathrm{mmHg}$ (greater than $40 \mathrm{mmHg}$ in ten) during the follow-up period. Eight of these had raised IOP on the first post-operative day and three had been on timolol since that time. Seven eyes with raised IOP had an oil-filled anterior chamber, one developed glaucoma following 


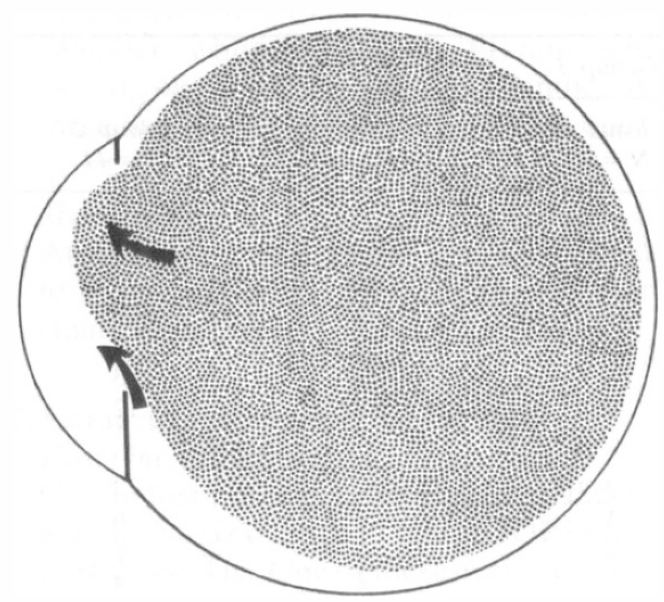

Fig. 2a Diagram illustrating the influence of a superior sector iridectomy on the position of the silicone-oil globule and on the flow of aqueous into the anterior chamber in the aphakic eye.

further injection of silicone oil and another was noted to have extensive peripheral anterior synechiae. There was no apparent reason for raised IOP in the other ten.

Two eyes with an IOP of greater than $40 \mathrm{mmHg}$ required a paracentesis to relieve acute pupillary block-in one case on two occasions. This latter case eventually required insertion of a Molteno-type drainage tube. Another eye, with raised IOP and an oil-filled anterior chamber, underwent removal of silicone oil with a resultant fall in the IOP to normal. Oil was also removed from two other eyes with raised IOP, although it did not fill their anterior chambers, in an unsuccessful attempt to control the IOP. A trabeculectomy was eventually performed on one, while the other underwent insertion of a drainage tube.

Medical therapy for glaucoma was commenced in 14 of the eyes with raised IOP and was continued in the three which had been on treatment since the first post-operative day.

\section{Six months (Table V)}

At six months normal IOP was recorded in 32 eyes in Group II. Nine of these eyes required the use of timolol, one had undergone trabeculectomy and another insertion

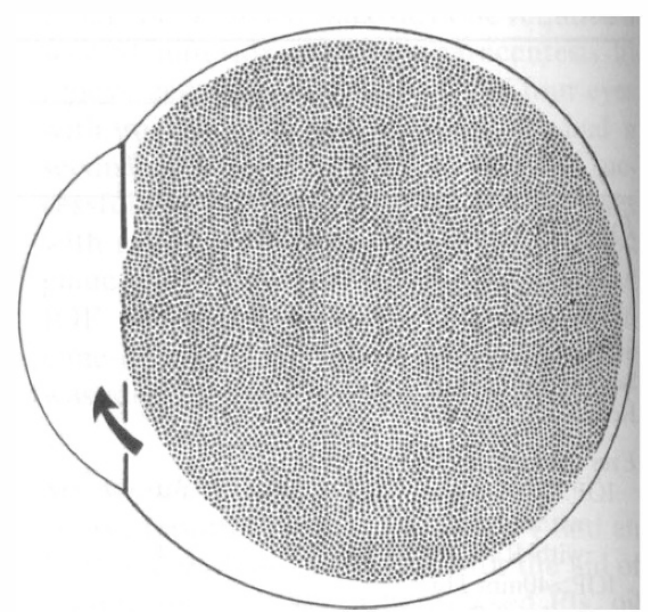

Fig 2b The superior iris remains intact, discouraging silicone oil/corneal contact, while aqueous can pass freely into the anterior chamber through an iridectomy at the six o'clock position.

of a Molteno tube. Of the eyes with normal IOP, oil filled the anterior chamber in seven and had been removed from three. Six eyes with an oil-filled anterior chamber did not require treatment (in five the retina was detached). In the eye with oil in the anterior chamber which did require treatment for glaucoma, the retina was attached.

Twelve eyes in Group II had raised IOP (greater than $40 \mathrm{mmHg}$ in four), despite treatment in six, at six months. Four (two of which had an IOP of greater than $40 \mathrm{mmHg}$ ) had oil-filled anterior chambers, one had extensive peripheral anterior synechiae and another had intractable glaucoma which had required insertion of a Molteno tube. In the other six eyes no obvious reason for raised IOP was identified.

\section{Corneal Status (Table VI)}

Seventeen of the 44 eyes with a superior SI had developed keratopathy by the end of the six-month follow-up period. In nine of these eyes oil filled the anterior chamber at six months and another three were noted to have an oil-filled anterior chamber at some stage during the six month follow-up period, the oil having been removed from one four months following surgery. Of the 
Table VII Incidences of anterior segment complications

(a) OVERAL INCIDENCE OF OIL IN AC

\begin{tabular}{ccc}
\hline & Group 1 & \\
\hline $\begin{array}{c}\text { Open PI } \\
(N=25)\end{array}$ & $\begin{array}{c}\text { Closed PI } \\
(N=19)\end{array}$ & $\begin{array}{c}\text { Group 2 } \\
(N=44)\end{array}$ \\
\hline $0 \%$ & $84 \%$ & $50 \%$ \\
\hline
\end{tabular}

(b) INCIDENCES OF GLAUCOMA

\begin{tabular}{|c|c|c|c|c|}
\hline & \multicolumn{3}{|c|}{ Group 1} & \multirow[b]{2}{*}{$\begin{array}{l}\text { Group } 2 \\
(N=44)\end{array}$} \\
\hline & Open PI & Closed PI & $\begin{array}{c}\text { Total } \\
(N=44)\end{array}$ & \\
\hline $\begin{array}{l}\text { Day one } \\
\text { IOP }>25 \mathrm{~mm} \mathrm{Hg}\end{array}$ & $\begin{array}{c}(N=37) \\
43 \%\end{array}$ & $\begin{array}{c}(N=7) \\
86 \%\end{array}$ & $50 \%$ & $57 \%$ \\
\hline $\begin{array}{l}\text { Interim } \\
\text { IOP }>25 \mathrm{~mm} \mathrm{Hg}\end{array}$ & $\begin{array}{c}(N=35) \\
29 \%\end{array}$ & $\begin{array}{c}(N=9) \\
44 \%\end{array}$ & $32 \%$ & $43 \%$ \\
\hline $\begin{array}{l}6 \text { months } \\
\mathrm{IOP}>25 \mathrm{~mm} \mathrm{Hg}\end{array}$ & $\begin{array}{c}(N=34) \\
12 \%\end{array}$ & $\begin{array}{c}(N=10) \\
30 \%\end{array}$ & $16 \%$ & $27 \%$ \\
\hline
\end{tabular}

(c) OVERALL INCIDENCE OF KERATOPATHY

\begin{tabular}{cccc}
\hline Group 1 & \\
\hline $\begin{array}{c}\text { Closed PI } \\
\text { Opter day one } P I \\
(N=30)\end{array}$ & $\begin{array}{c}\text { Total } \\
(N=44)\end{array}$ & $\begin{array}{c}\text { Group } 2 \\
(N=44)\end{array}$ \\
\hline $3 \%$ & $36 \%$ & $14 \%$ & $39 \%$ \\
\hline
\end{tabular}

Table VIII Outcome of secondary PIs in 5 eyes

\begin{tabular}{lccc}
\hline Procedure & Number performed & Unsuccessful & Successful \\
\hline Yag laser iridotomy & 5 & 5 & - \\
Outcome iridectbmy & 5 & 2 & 3 \\
\hline
\end{tabular}

remaining five eyes with keratopathy the position of the anterior silicone-oil face could not be confirmed from the hospital records.

Six of the 17 eyes with keratopathy had an IOP of greater than $25 \mathrm{mmHg}$ for a period of several months during the six-month follow-up period.

In seven of the 12 eyes in which silicone oil had filled the anterior chamber and four of the five eyes in which the position of the oil face was unknown, the retina was detached at six months.

\section{Discussion}

Serious complications of silicone oil in the aphakic eye arise from its interference with aqueous outflow and disturbance of function in the corneal endothelium.

Prior to Ando's innovation we had considered that a large superior SI would discourage silicone oil from entering the anterior chamber by facilitating the passage of aqueous from the posterior to the anterior chamber around the anterior face of the silicone-oil globule. A superior SI, however, allows oil to move into the upper part of the anterior chamber, even when there is free flow of aqueous into the anterior chamber inferiorly (Fig. 2a).

A peripheral iridectomy at the six o'clock position should be more efficient at maintain- 


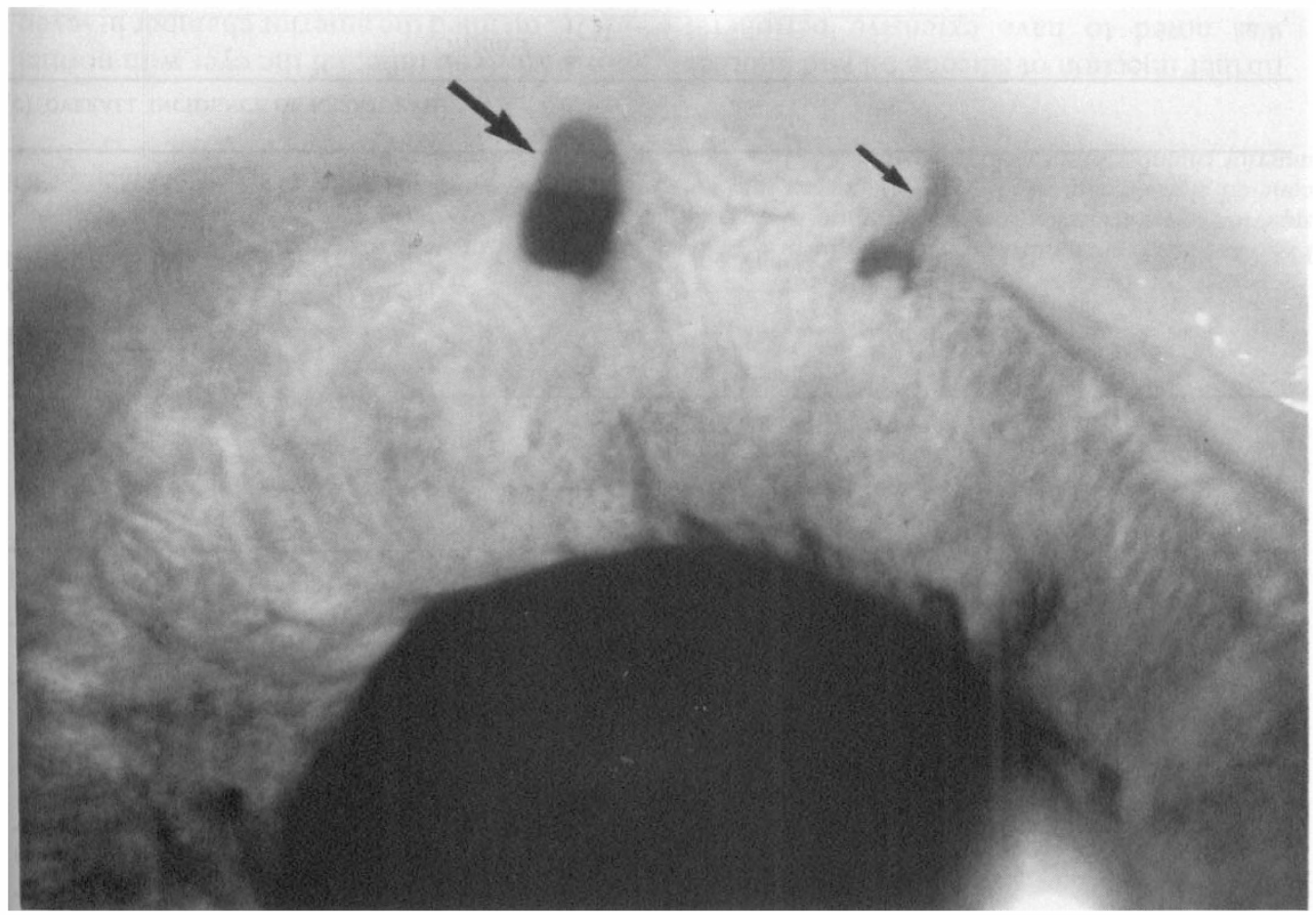

Fig. 3 A case in which the six o'clock iridectomy closed (small arrow), causing acute pupillary-block glaucoma. A secondary iridectomy (large arrow) was created, using the Ocutome.

ing an oil-free anterior chamber, because it not only ensures the forward flow of aqueous inferiorly and so averts pupillary block, but because the intact physical boundary of the anterior chamber superiorly restrains the silicone-oil globule from moving forwards into the anterior chamber (Fig. 2b).

The results of this study suggest that a six o'clock PI, provided that it remains patent, is more effective than a superior SI in preventing anterior segment complications in the aphakic eye treated with silicone-oil injection. During the six-month follow-up period oil was never observed in the anterior chamber of eyes with an open PI, but was observed in $50 \%$ of eyes with a superior SI. Of Group I eyes in which the PI closed, however, $84 \%$ were noted to have an oil-filled anterior chamber (Table VIIa).

Raised IOP on the first post-operative day occurred in slightly fewer eyes in Group I $(50 \%)$ than Group II $(57 \%)$, the incidence being lowest in eyes with an open six o'clock PI $(43 \%)$ and highest in those in which it was closed (86\%) (Table VIIb). Acute pupillaryblock glaucoma occurred only in eyes with a superior SI or those with a closed six o'clock PI. Of the eyes with a closed PI, four out of six required paracentesis to relieve pupillary block, while in all those with a superior SI it resolved with posturing alone.

During the subsequent six months, an IOP of greater than $25 \mathrm{mmHg}$ was recorded in $43 \%$ of eyes in Group II and in $44 \%$ of eyes with a closed PI in Group I, but in only $29 \%$ of eyes with an open PI (Table VIIb). At the end of six months the prevalence of raised IOP was higher in Group II eyes $(27 \%)$ than in those with an open PI (12\%), but was similar to that in eyes with a closed PI (30\%) (Table VIIb).

The prevalence of keratopathy at six months was less in Group I (14\%) than in Group II $(39 \%)$. The difference was more striking when comparing eyes with an open six o'clock PI (3\%) with those in Group II (39\%), and even in eyes with a closed six o'clock PI the prevalence of keratopathy was slightly 
lower than in those with a superior SI (Table VIIc).

Our findings confirm those of previous authors, ${ }^{37,38}$ suggesting that the six o'clock PI provides an effective method for preventing silicone oil from entering the anterior chamber of the aphakic eye, thereby reducing the incidence of glaucoma and keratopathy. In 19 out of 44 cases in this series (43\%), however, the PI closed at some stage during the six month follow-up period, while ten $(23 \%)$ did not have a functioning iridectomy after six months. Given that the consequences of nonpatency are so serious, the general acceptance of this method must be qualified in two ways; firstly as Ando emphasised, ${ }^{37}$ the six o'clock PI should be sufficiently large to discourage closure and secondly, if it is necessary to create a secondary PI at the six o'clock position, this should be done surgically rather than with the YAG laser (Table VIII) (Fig. 3).

While recognising that the conclusions which can be drawn from a retrospective study are limited, we nevertheless deduce that a patent six o'clock PI is effective in reducing the anterior segment complications of intraocular silicone oil in the aphakic eye.

We thank Miss Clare Bunt and Miss Penelope Leaver for typing the manuscript and the department of Medical Illustration, Moorfields Eye Hospital, for help with the figures.

\section{References}

${ }^{1}$ Ando F, Miyake Y, Oshima K, Yamanaka A: Temporary Use of Intraocular Silicone Oil in the Treatment of Complicated Retinal Detachment. Graefe's Arch Clin Exp Ophthalmol 1986, 224: 32-6

${ }^{2}$ Bacin F and Gibert C: Resultats du Traitment des Decollements de Retine avec Retraction du Vitre par Injections de Silicone Liquide Intraoculaire. Bull Soc Ophthalmol Fr 1982, 82: 367-72.

${ }^{3}$ Barthelemy F: Utilisation de l'Huile de Silicone en Tamponnement Transitoire dans le Traitement des Decollements de Retine avec Retraction Vitreoretinienne. I. Resultats Anatomiques et Fonctionnels a Court et Longtermes sur 110 cas. $J$ Fr Ophthalmol 1984, 7: 723-77.

${ }^{4}$ Cibis PA, Becker B, Okun E, Canaan S: The Use of Liquid Silicone in Retinal Detachment Surgery. Arch Ophthalmol 1962, 68: 590-9.

${ }^{5}$ Constable I, Mohamed S, Tan PL: Super Viscous Silicone Liquid in Retinal Surgery. Aust $J$ Ophthalmol 1982, 10: 5-11.

${ }^{6}$ Cox MS, Trese MT, Murphy PL: Silicone Oil for Advanced Proliferative Vitreoretinopathy. Ophthalmology 1986, 93: 646-50.
${ }^{7}$ Dufour R: Experience with Intraocular Silicone Injection. New and Controversial Aspects of Retinal Detachment Surgery. (Harper and Row, New York, 1968), p.377.

${ }^{8}$ Freeman WR, Henderly DE, Lee Wan W, Causey D, Trousdale M, Green RL, Rao NA: Prevalence, Pathophysiology and Treatment of Rhegmatogenous Retinal detachment in Treated Cytomegalovirus Retinitis. Am J Ophthalmol 1987, 103: 527-36.

${ }^{9}$ Gnad H, Skorpik C, Paroussis P, Radda TM, Klemen UM, Lessel MR, Thaler A, Heilig P: Funktionelle und Anatomische Resultate nach Temporare Silikon Implantation. Klin Monatsbl Augenheilk 1984, 185: 364-7.

${ }^{10}$ Gonvers M: Temporary Silicone Oil Tamponade in the Management of Retinal Detachment with Proliferative Vitreoretinopathy. Am J Ophthalmol 1985, 100: 239.

11 Grey RHB and Leaver PK: Silicone Oil in the Treatment of Massive Preretinal Retraction. 1: Results in 105 Eyes, Br J Ophthalmol 1979, 63: 355-60.

${ }^{12}$ Haut J, Ullern M, Chatellier P, Cedah A: Resultats de 200 Cas d'Injection Intraoculaire de Silicone Associee a la Vitrectomie. Bull Mem Soc Fr Ophthalmol 1979, 91: 180-4.

${ }^{13}$ Heimann K, Dimopoulos S, Paulmann H: Silikonolinjektion in der Behandlung Komplizierten Netzhautablosungen. Klin Mbl Augenheilk 1984, 185: 505-8.

${ }^{14}$ Kampik A, Gabel VP, Spiegel D: Intraoculare Tamponade mit Hochviskosem Silikonel bei Massiver Proliferativer Vitreoretinopathie. Kln $\mathrm{Mbl}$ Augenheilk 1984, 185: 368-70.

${ }^{15}$ Laqua H, Lucke K, Foerster MH: Development and Present Status of Silicone Oil Surgery. Klin Monatsbl Augenheilkd 1988, 192: 277-83.

${ }^{16}$ Lean JS, Leaver PK, Cooling RJ, McLeod D: Management of Complex Retinal Detachments by Vitrectomy and Fluid/Silicone Exchange. Trans Ophthalmol Soc UK 1982, 102: 203-5.

${ }^{17}$ Leaver PK, Cooling RJ, Feretis EB, Lean JS, McLeod D: Vitrectomy and Fluid/Silicone-Oil Exchange for Giant Retinal Tears: Results at Six Months. Br J Ophthalmol 1984, 68: 432-8.

${ }^{18}$ Lucke $\mathrm{KH}$, Foerster MH, Laqua H: Long-term Results of Vitrectomy and Silicone Oil in 500 cases of Complicated Retinal Detachments. Am J Ophthalmol 1987, 104: 624-33.

${ }^{19}$ McCuen B, Landers MB, Machemer R: The use of Silicone Oil Following Failed Vitrectomy for Retinal Detachment with Advanced Proliferative Vitreoretinopathy. Ophthalmology 1985, 92: 1029-33.

${ }^{20}$ McLeod D: Silicone Oil Injection During Closed Microsurgery for Diabetic Retinal Detachment. Graefes Arch Clin Expl Ophthalmol 1986, 224: 55-9.

${ }^{21}$ Okun E and Arribas . NP: Therapy of Retinal Detachment Complicated by Massive Preretinal Fibroplasia (Long-term Follow-up of Patients treated with Intravitreal Liquid Silicone) In: Symposium on Retina and Retinal Surgery; Trans- 
actions of the New Orleans Academy of Ophthalmology 1969, St Louis: CV Mosby, 27893.

22 Rosengren B: Intravitreous Injection of Liquid Silicone for Retinal Detachment. Trans Swedish Ophthalmol Soc. Acta Ophthalmol 1966, 44: 975-6.

${ }^{23}$ Ruellan YM and Roussat D: Decollement de Retine: Tamponnement Interne Provisoire par Huile de Silicone apres Vitrectomie. Resultats Anatomiques et Fonctionnels. J Fr Ophthalmol 1985, 8: 117-24.

${ }^{24}$ Scott JD: A Rationale for the Use of Liquid Silicone. Trans Ophthalmol Soc UK 1977, 97: 235-7.

${ }^{25}$ Stern WH, Johnson RN, Irvine AR: Extended Retinal Tamponade in the Treatment of Retinal Detachment with Proliferative Vitreoretinopathy. Br J Ophthalmol 1986, 70: 911-17.

${ }^{26}$ Unosson K, Stenkula S, Tornquist P, Weijdegard L: Liquid Silicone in the Treatment of Retinal Detachment. Acta Ophthalmol 1985, 63: 656-60.

${ }^{27}$ Yeo JH, Glaser BM, Michels RG: Silicone Oil in the Treatment of Complicated Retinal Detachments. Ophthalmology 1987, 94: 1109-113.

${ }^{28}$ Zivojnovic R, Mertens DAE, Peperkamp E: Das Flussige Silikon in der Amotiochirurgie. 2: Bericht uber 280 Fall-weitere Entwicklung der Technik. Kln Mbl Augenheilk 1982, 181: 444-52.

${ }^{29}$ Alexandridis E and Daniel H: Results of Silicone Oil Injection into the Vitreous. Dev Ophthalmol 1981, 2: 24-27 (Karger, Basel).

${ }^{30}$ Chan C and Okun E: The Question of Ocular Toler- ance to Intravitreal Liquid Silicone. A Long-term Analysis. Ophthalmology 1986, 93: 651.

${ }^{31}$ Haut J, Ullern M, Chermet M, van Effenterre G: Complications des Injections Intraoculaires de Silicone. Bull Soc Ophthalmol Fr 1980, 80: 51923

${ }^{32}$ Leaver PK, Grey RHB, Garner A: Silicone Oil Injection in the Treatment of Massive Preretinal Retraction. II: Late Complications in 93 Eyes. $\mathrm{Br}$ J Ophthalmol 1979, 63: 361-7.

${ }_{33}$ McCuen B, de Juan E, Landers MB, Machemer R: Silicone Oil in Vitreoretinal Surgery. 2: Results and Complications Retina 1985, 5: 198-205.

${ }^{34}$ Roussat B and Ruellan YM: Traitement du Decollement de Retine par Vitrectomie et Injection d'Huile de Silicone. Resultats a Long Terme et Complications dans 105 CAs. J Fr Ophthalmol 1984, 7: 11-18.

${ }^{35}$ Sell CH, McCuen BW, Landers MB, Machemer R: Long-term Results of Successful Vitrectomy with Silicone Oil for Advanced Proliferative Vitreoretinopathy. Am J Ophthalmol 1987, 103: 24-8.

36 Tavakolian $\mathrm{U}$ and Wollensak J: Komplikationen nach Silikonolinjektion. Klin $\mathrm{Mbl}$ Augenheilkunde 1985, 187: 556.

37 Ando F: Intraocular Hypertension resulting from Pupillary Block by Silicone Oil. Am J Ophthalmol 1985, 99: 87-8.

${ }^{38}$ Beekhuis WH, Ando F, Zivojnovic ER, Mertens DAE: Basal Iridectomy at six o'clock in the Aphakic Eye treated with Silicone Oil: Prevention of Keratopathy and Secondary Glaucoma. $\mathrm{Br}$ J Ophthalmol 1987, 71: 197-200. 